
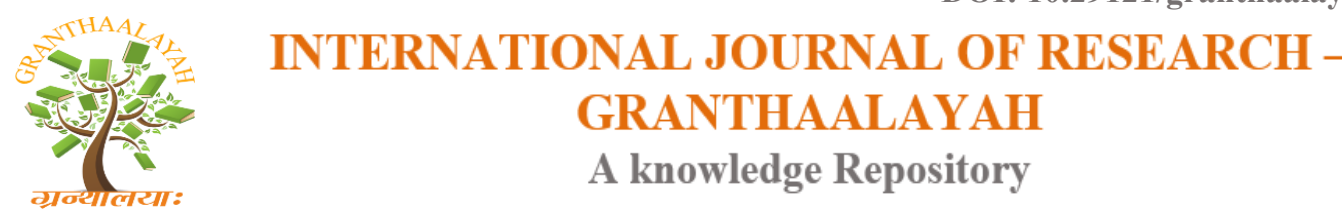

口ifit口

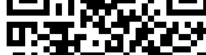

Science

\title{
FACTORS AFFECTING COPPER REMOVAL FROM SIMULATED WASTEWATER USING RICE HUSK ASH AS AN ADSORBENT
}

\author{
Kashif Imran $^{* 1}$, Dildar Ahmed ${ }^{2}$, Naseem Zahra ${ }^{3}$ \\ ${ }^{* 1,2}$ Forman Christian College, Lahore, PAKISTAN \\ ${ }^{3}$ PCSIR Laboratories Complex, Lahore, PAKISTAN
}

\begin{abstract}
The present study entails the effect of various factors affecting removal of copper from simulated wastewater by using rice husk ash as an adsorbent. Various standard solutions of copper nitrate were prepared and treated with rice husk ash (RHA) to investigate adsorption on the adsorbent under different conditions of $\mathrm{pH}$, temperature, time and adsorbate dose. Maximum removal of $\mathrm{Cu} 2+$ was observed at its low concentration of $10 \mathrm{ppm}$ at $50{ }^{\circ} \mathrm{C}$ and 90 minutes contact time. The percentage adsorption decreased with increase in concentration of Cu2+. The removal of $30 \mathrm{ppm}$ and $40 \mathrm{ppm} C \mathrm{Cu}+$ solutions was maximum at $\mathrm{pH} 6$ and 8 , respectively. It was concluded that $\mathrm{RHA}$ can be used for Cu2+ removal from wastewater containing copper ions by suitably optimizing the conditions.
\end{abstract}

Keywords:

Copper, Adsorbent, Rice husk ash, Simulated wastewater.

Cite This Article: Kashif Imran, Dildar Ahmed, and Naseem Zahra, "FACTORS AFFECTING COPPER REMOVAL FROM SIMULATED WASTEWATER USING RICE HUSK ASH AS AN ADSORBENT" International Journal of Research - Granthaalayah, Vol. 4, No. 2 (2016): 52-61.

\section{INTRODUCTION}

Copper is a heavy metal and when it exceeds permissible limits it may harm to human health (Shukla et al., 2002). The copper contamination, its toxicity and its removal from drinking water using different adsorbents were investigated (Naseem et al. 2014). The low cost adsorbents which can be used for copper removal are saw dust, pine fruit and activated carbon. Yates et al. (1998) performed experiments to study the copper uptake by colloidal $\mathrm{SiO}_{2}$ in aqueous solutions. These solutions were merged with $\mathrm{CuCl}_{2}$ solutions. The solutions were equilibrated for 24 hours. Formation of copper silicates like chrysocolla occurs under acid conditions in supergene copper deposits. The removal of heavy metals through adsorption technique was found to be a practical purification technique which has been used commonly in various industries especially for wastewater treatments (Naeem et al., 2010). Percentage adsorption for RHA-Copper solution system was calculated. 
Larous et al. (2003) investigated the copper removal from aqueous solutions using saw dust as an adsorbent. The mechanism of $\mathrm{Cu}^{2+}$ adsorption on pine fruit as solid adsorbent was studied and it was found that this adsorbent removes 96-97\% copper (Tariq et al., 2009).

The effects of various parameters, such as $\mathrm{pH}$ of solution, contact time, temperature and adsorbate concentration were studied. It was observed that adsorption of copper increased with increasing time, temperature, $\mathrm{pH}$ and decreased with increasing adsorbate concentration (Naeem et al., 2010).

The adsorption method was found to be profitable due to use of low cost adsorbents, ease of use, accessibility of adsorbents and low operational cost. The adsorption technique is environment friendly, time saving and simple and involves use of simple equipment and apparatus. Similarly, rice husk ash is low cost adsorbent (Zahra et al., 2009; Zahra 2009; Zahra et al., 2009 and Zahra 2010).

The present study aims to study the effects of various factors affecting adsorption of copper from the simulated wastewater using rice husk ash as an adsorbent.

\section{MATERIALS AND METHODS}

The reagents used in the present study were of analytical grade received from (MERCK) ${ }^{\mathrm{TM}}$. Copper nitrate solutions used in this work were prepared in de-ionized water. Rice husk ash (RHA) obtained from PCSIR Laboratories Complex, Lahore was prepared by igniting at $750{ }^{\circ} \mathrm{C}$. It was then ground to -200 mesh and was used without any chemical treatment for the present experimental work. Atomic absorption spectrometer "Perkin Elmer A Analyst AAS" was used to determine the concentration of copper in each filtrate. The hollow-cathode lamp of copper metal was used. Simulated wastewater was prepared by dissolving $2.95 \mathrm{~g}$ of $\mathrm{Cu}\left(\mathrm{NO}_{3}\right)_{2}$ in a volumetric flask $(1000 \mathrm{~mL})$ and increasing the volume upto the mark. $1000 \mathrm{ppm}$ of $\mathrm{Cu}\left(\mathrm{NO}_{3}\right)_{2}$ solution was used as stock solution. The concentrations of $\mathrm{Cu}^{2+}$ after treatment of the standard solutions with RHA under various conditions of $\mathrm{pH}$, temperature, adsorbate dose and time were determined by AAS. Percentage adsorption was calculated by using the following formula.

\% adsorption $=100\left[\left(C_{i}-C_{f}\right) / C_{i}\right]$

Where; $C_{i}$ and $C_{f}$ are final concentrations of $\mathrm{Cu}^{2+}$ before and after the treatment with RHA.

\section{RESULTS AND DISCUSSION}

\section{EFFECT OF ADSORBATE DOSE ON ADSORPTION}

Effect of concentration of copper ions on adsorption on rice husk ash was studied by varying the initial concentration of $\mathrm{Cu}^{2+}$ solutions $(10 \mathrm{ppm}-80 \mathrm{ppm})$. The results are given in Table 1 . 
Table 1: Effect of adsorbate dose on adsorption of $\mathrm{Cu} 2+$ by $\mathrm{RHA}(5 \mathrm{~g})$, at $\mathrm{pH} 7$, for contact time 30 min at $32{ }^{\circ} \mathrm{C}$

\begin{tabular}{|l|l|l|l|}
\hline $\begin{array}{c}\text { Sr. } \\
\text { No. }\end{array}$ & $\begin{array}{c}\text { Initial concentration of } \\
\mathbf{C u}^{2+}(\mathbf{p p m})\end{array}$ & $\begin{array}{c}\text { Final concentration of } \\
\mathbf{C u}^{2+}(\mathbf{p p m})\end{array}$ & $\begin{array}{c}\text { \%age } \\
\text { adsorption }\end{array}$ \\
\hline 1 & 10 & 0.00 & 100.0 \\
\hline 2 & 20 & 0.94 & 95.3 \\
\hline 3 & 30 & 4.80 & 84.0 \\
\hline 4 & 40 & 10.19 & 74.5 \\
\hline 5 & 50 & 15.89 & 68.2 \\
\hline 6 & 60 & 21.35 & 64.4 \\
\hline 7 & 70 & 26.80 & 61.7 \\
\hline 8 & 80 & 34.00 & 57.5 \\
\hline
\end{tabular}

A graph was plotted between the initial concentration of adsorbate $(\mathrm{Cu})$ and \% adsorption. For this purpose, different copper standards ranging from 10-80 ppm were taken along the horizontal axis while the $\%$ adsorption was along the vertical axis.

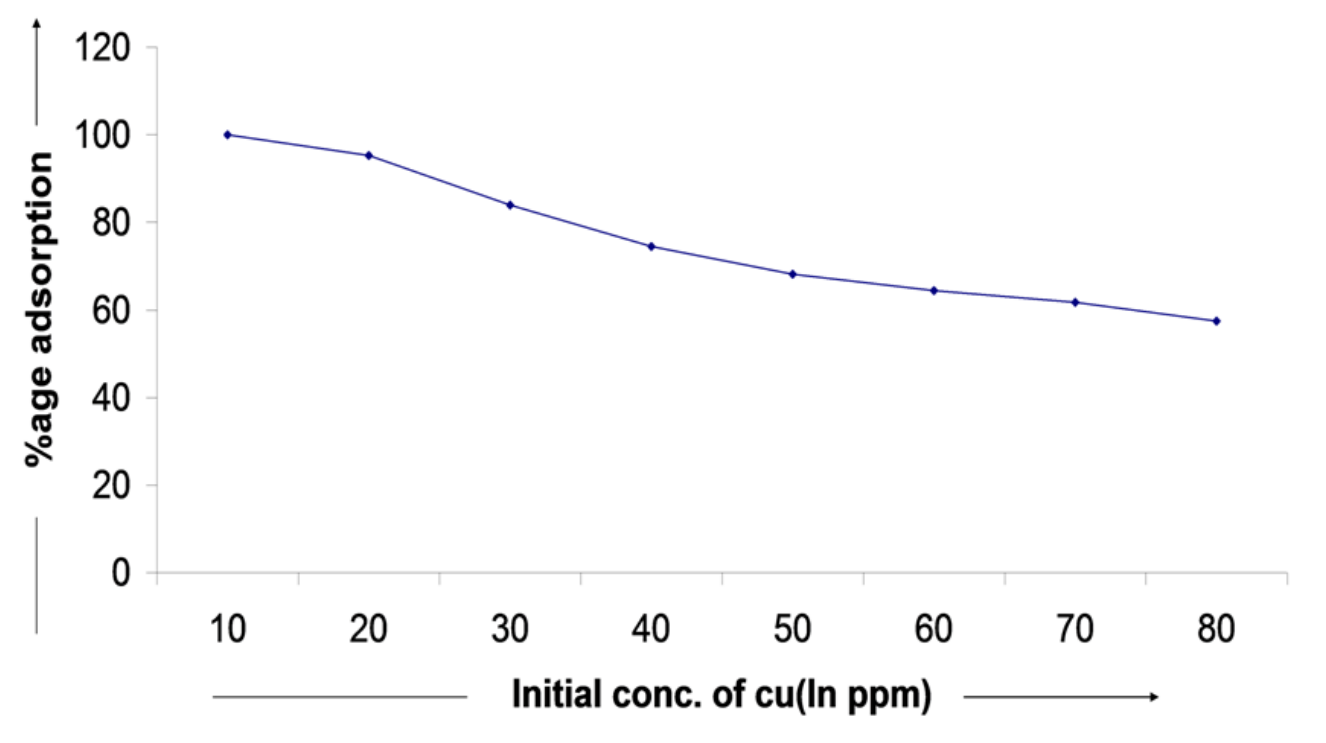

Figure 1: Effect of adsorbate dose on adsorption on RHA

Effect of adsorbate dose on adsorption of $\mathrm{Cu}^{2+}$ on rice husk ash was studied by varying the initial concentration of copper solutions. The process of adsorption has an inverse relationship with the adsorbate dose. As figure 1 show, maximum adsorption was observed when the initial conc. of $\mathrm{Cu}^{2+}$ was the lowest. It was concluded that the decrease in adsorption of ion with the increase of 
their concentration may be attributed the phenomenon of ion exchange as has been suggested by Rameshwar et al. (1996). In addition less favorable lattice positions or exchange sites become involved with increasing metal concentration.

\section{EFFECT OF TIME ON ADSORPTION}

The effects of contact time on the amount of metal ions on adsorbent surface are shown in Table 2. $\mathrm{Cu}^{+2}$ solution of $40 \mathrm{ppm}$ was used in order to study the effect of time for copper adsorption.

Table 2: Effect of time on adsorption of $\mathrm{Cu} 2+$ by $\mathrm{RHA}(5 \mathrm{~g}), \mathrm{pH} 7$, at $32{ }^{\circ} \mathrm{C}$

\begin{tabular}{|l|l|l|l|l|}
\hline Sr. No. & $\begin{array}{l}\text { Initial } \\
\text { concentration } \\
\text { of } \mathbf{C u}^{2+}(\mathbf{p p m})\end{array}$ & $\begin{array}{l}\text { Time (minutes) given } \\
\text { for adsorption }\end{array}$ & $\begin{array}{c}\text { Final } \\
\text { concentration } \\
\text { of } \mathbf{C u}^{2+}(\mathbf{p p m})\end{array}$ & $\begin{array}{c}\text { \%age } \\
\text { adsorption }\end{array}$ \\
\hline 1 & 40 & 15 & 9.94 & 75.15 \\
\hline 2 & 40 & 30 & 8.43 & 78.9 \\
\hline 3 & 40 & 60 & 9.06 & 82.3 \\
\hline 4 & 40 & 90 & 5.74 & 85.6 \\
\hline 5 & 40 & 120 & 8.67 & 78.3 \\
\hline
\end{tabular}

A graph was plotted between the various time intervals and \% adsorption. For this purpose, the $\%$ adsorptions of copper standard $(40 \mathrm{ppm})$ at various time intervals were taken along horizontal axis while the $\%$ adsorption was plotted along the vertical axis.

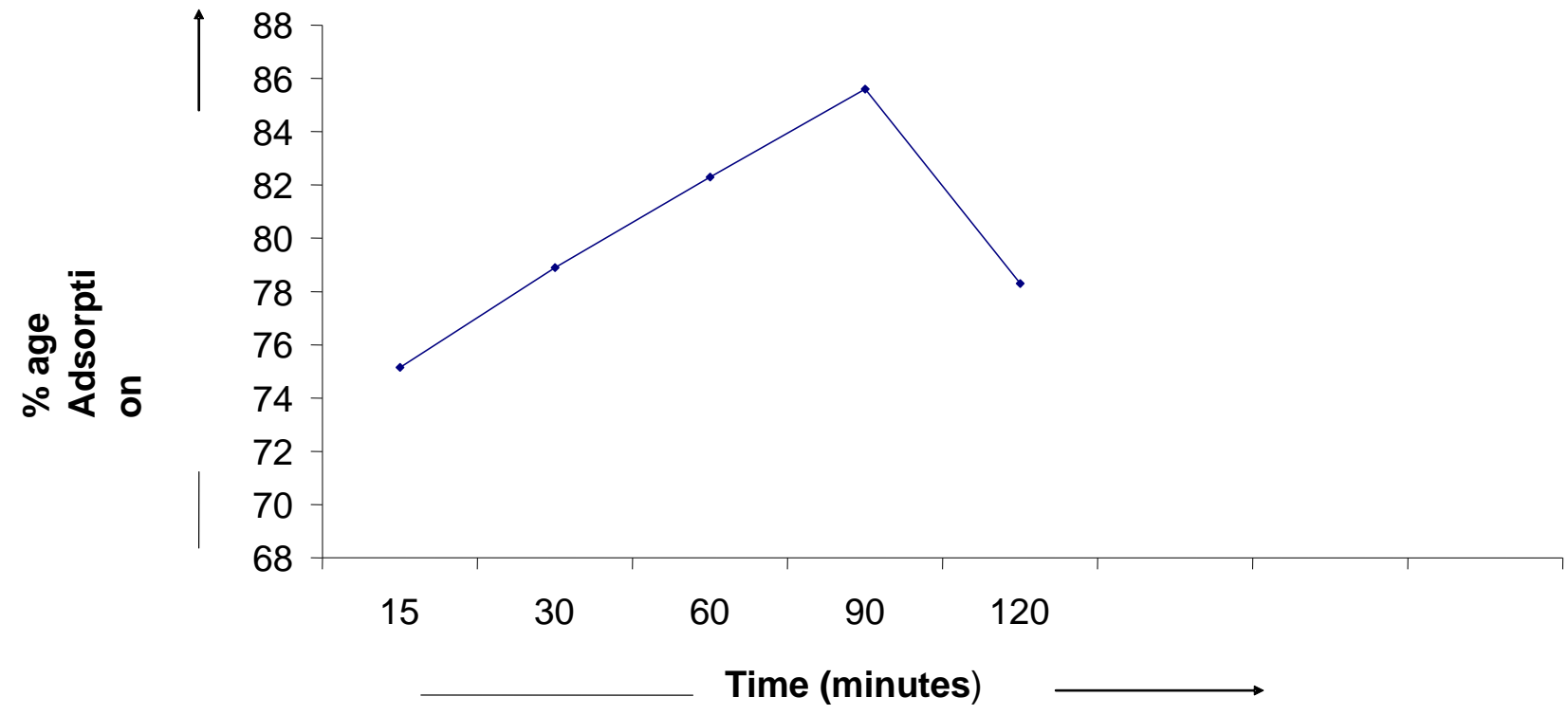

Figure 2: Effect of time on adsorption of copper 
Effect of time on adsorption of $\mathrm{Cu}^{2+}(40 \mathrm{ppm})$ on rice husk ash was studied by varying the time intervals taken for adsorption. Adsorption of copper was varied by varying the time for adsorption. As figure 2 show, maximum adsorption was at 90 minute. As the time passes the adsorption increases. But after 2 hours, desorption of copper was observed.

\section{EFFECT OF TEMPERATURE ON ADSORPTION}

Effect of temperature on copper adsorption was observed. Three concentrations of copper solution $(20,30,40 \mathrm{ppm})$ were studied at five different temperature ranges $\left(15,32,50,65\right.$ and $\left.80^{\circ} \mathrm{C}\right)$.

Table 3.1: Effect of temperature on adsorption of $\mathrm{Cu} 2+$ by $\mathrm{RHA}(5 \mathrm{~g}), \mathrm{pH} 7$, for contact time 30

\begin{tabular}{|c|c|c|c|}
\hline Sr. No. & $\begin{array}{l}\text { Initial concentration of } \\
\mathrm{Cu}^{2+}(\mathrm{ppm})\end{array}$ & $\begin{array}{c}\text { Final } \\
\text { concentration of } \\
\mathrm{Cu}^{2+}(\mathrm{ppm})\end{array}$ & \%age adsorption \\
\hline 1 & 20 & 2.74 & 86.3 \\
\hline 2 & 30 & 7.50 & 75.0 \\
\hline 3 & 40 & 11.53 & 68.2 \\
\hline
\end{tabular}

Table 3.2: Effect of temperature on adsorption of $\mathrm{Cu} 2+$ by $\mathrm{RHA}(5 \mathrm{~g}), \mathrm{pH} 7$, for contact time 30 $\min$ at $32{ }^{\circ} \mathrm{C}$

\begin{tabular}{|l|l|l|l|}
\hline Sr. No. & $\begin{array}{l}\text { Initial concentration of } \\
\mathbf{C u}^{2+}(\mathbf{p p m})\end{array}$ & $\begin{array}{l}\text { Final conc. of } \mathbf{C u}^{2+} \\
(\mathbf{p p m})\end{array}$ & \%age adsorption \\
\hline 1 & 20 & 3.40 & 89.2 \\
\hline 2 & 30 & 6.54 & 78.2 \\
\hline 3 & 40 & 12.0 & 70.0 \\
\hline
\end{tabular}

Table 3.3: Effect of temperature on adsorption of $\mathrm{Cu} 2+$ by $\mathrm{RHA}(5 \mathrm{~g}), \mathrm{pH} 7$, for contact time 30 $\min$ at $50{ }^{\circ} \mathrm{C}$

\begin{tabular}{|l|l|l|l|}
\hline Sr. No. & $\begin{array}{l}\text { Initial concentration of } \\
\mathbf{C u}^{2+}(\mathbf{p p m})\end{array}$ & $\begin{array}{l}\text { Final concentration } \\
\text { of } \mathbf{C u}^{2+}(\mathbf{p p m})\end{array}$ & \%age adsorption \\
\hline 1 & 20 & 1.45 & 92.7 \\
\hline 2 & 30 & 5.50 & 81.7 \\
\hline 3 & 40 & 11.06 & 72.3 \\
\hline
\end{tabular}


Table 3.4: Effect of temperature on adsorption of $\mathrm{Cu} 2+$ by $\mathrm{RHA}(5 \mathrm{~g}), \mathrm{pH} 7$, for contact time 30 $\min$ at $65^{\circ} \mathrm{C}$

\begin{tabular}{|l|l|l|l|}
\hline No. Sr. & $\begin{array}{l}\text { Initial concentration of } \\
\mathbf{C u}^{2+}(\mathbf{p p m})\end{array}$ & $\begin{array}{l}\text { Final concentration } \\
\text { of } \mathbf{C u}^{2+}(\mathbf{p p m})\end{array}$ & \%age adsorption \\
\hline 1 & 20 & 2.56 & 87.2 \\
\hline 2 & 30 & 6.39 & 78.7 \\
\hline 3 & 40 & 14.07 & 64.8 \\
\hline
\end{tabular}

Table 3.5: Effect of temperature on adsorption of $\mathrm{Cu} 2+$ by $\mathrm{RHA}(5 \mathrm{~g}), \mathrm{pH} 7$, for contact time 30 $\min$ at $80{ }^{\circ} \mathrm{C}$

\begin{tabular}{|l|l|l|l|}
\hline Sr. No. & $\begin{array}{l}\text { Initial concentration of } \\
\mathbf{C u}^{2+}(\mathbf{p p m})\end{array}$ & $\begin{array}{l}\text { Final concentration } \\
\mathbf{o f} \mathbf{C u}^{\mathbf{2}}(\mathbf{p p m})\end{array}$ & \% age adsorption \\
\hline 1 & 20 & 1.58 & 84.5 \\
\hline 2 & 30 & 4.30 & 77.6 \\
\hline 3 & 40 & 13.13 & 63.1 \\
\hline
\end{tabular}

A graph was plotted between the various temperature ranges and \% adsorption. For this purpose, the $\%$ adsorption of different copper standards (20 ppm $30 \mathrm{ppm}, 40 \mathrm{ppm})$ at various temperature ranges were taken. Various temperature ranges were taken along horizontal axis while the \% adsorption was plotted along the vertical axis.



Figure 3.1: Effect of temperature on adsorption of copper for $20 \mathrm{ppm}$ 


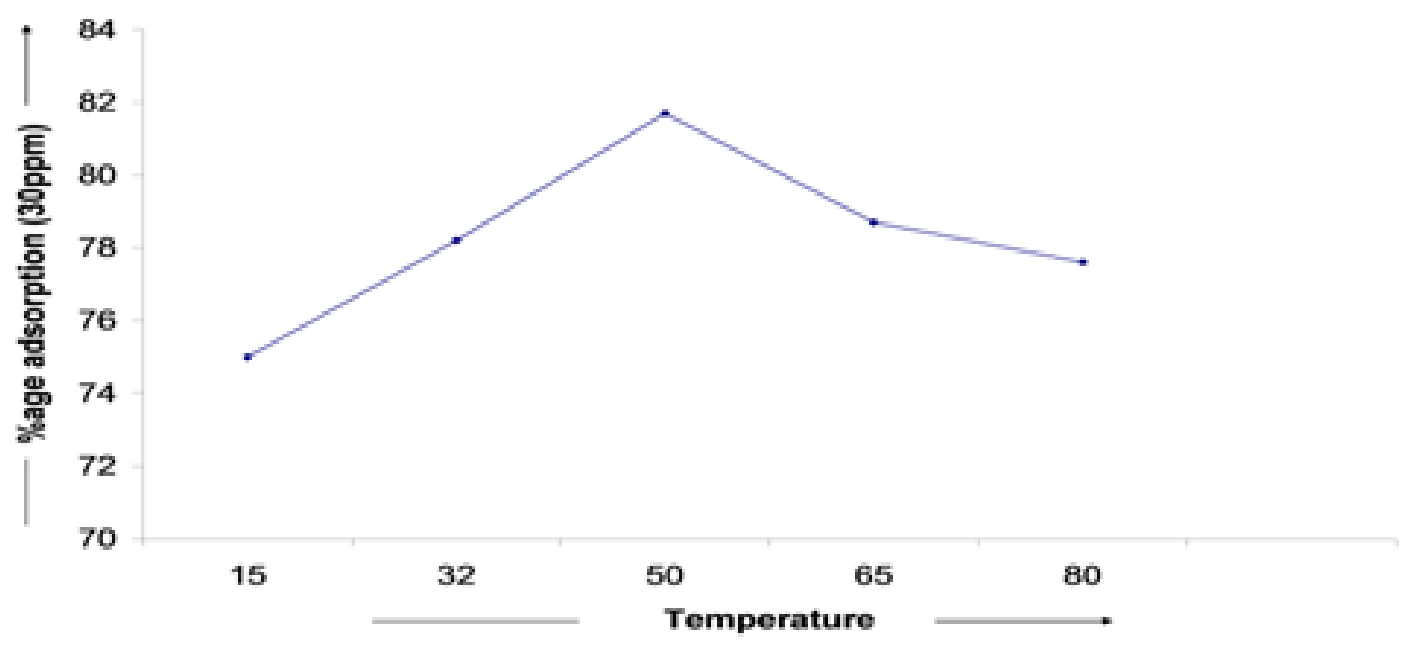

Figure 3.2: Effect of temperature on adsorption of copper for $30 \mathrm{ppm}$

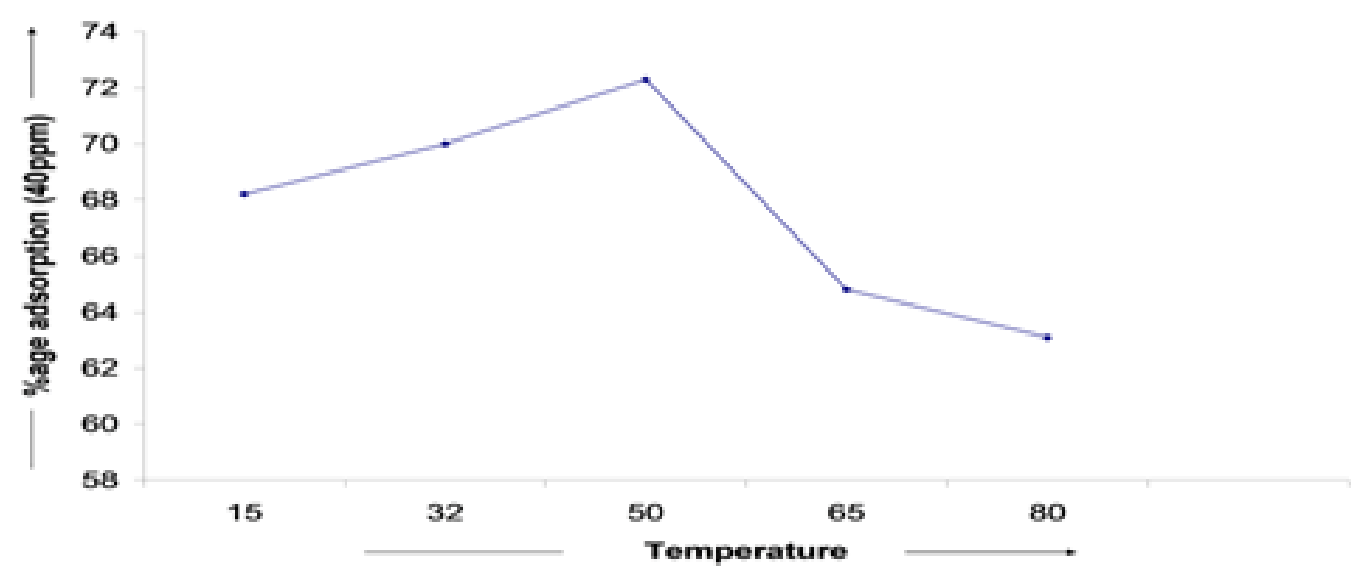

Figure 3.3: Effect of temperature on adsorption of copper for $40 \mathrm{ppm}$

Effect of temperature on $\mathrm{Cu}^{2+}$ adsorption on rice husk ash was studied at various temperature ranges. Effect of temperature on $20 \mathrm{ppm}, 30 \mathrm{ppm}$ and $40 \mathrm{ppm}$ copper standards was studied. In case of each of copper standards (20 ppm, $30 \mathrm{ppm}, 40 \mathrm{ppm})$, the maximum adsorption was noted at $50{ }^{\circ} \mathrm{C}$. However as the temperature increase beyond $50{ }^{\circ} \mathrm{C}$, desorption of $\mathrm{Cu}^{2+}$ was observed. Therefore, an increase in temperature after certain limit, decreased the adsorption of $\mathrm{Cu}^{2+}$ and favored desorption from rice husk ash. (Fig.3.1, 3.2, and 3.3)

\section{EFFECT OF PH ON ADSORPTION}

As the solution is acidic, so it is very necessary to control the heavy metals uptake. $\mathrm{pH}$ strongly affect \% copper removal and its uptake. 
Table 4.1: Effect of $\mathrm{pH}$ on adsorption of $\mathrm{Cu} 2+$ for $30 \mathrm{ppm}$ by $\mathrm{RHA}(5 \mathrm{~g})$, for contact time $30 \mathrm{~min}$ at $32{ }^{\circ} \mathrm{C}$

\begin{tabular}{|l|l|l|l|l|}
\hline Sr. No. & $\begin{array}{l}\text { Initial concentration } \\
\text { of } \mathbf{C u}^{2+}(\mathbf{p p m})\end{array}$ & $\mathbf{p H}$ & $\begin{array}{l}\text { Final } \\
\mathbf{C o n c e n t r a t i o n} \\
\mathbf{. o f} \mathbf{C u}^{2+}(\mathbf{p p m})\end{array}$ & \%age adsorption \\
\hline 1 & 30 & 02 & 21.54 & 28.2 \\
\hline 2 & 30 & 04 & 15.25 & 49.2 \\
\hline 3 & 30 & 06 & 1.47 & 95.1 \\
\hline 4 & 30 & 08 & 4.86 & 83.8 \\
\hline 5 & 30 & 10 & 9.74 & 67.5 \\
\hline 6 & 30 & 12 & 11.84 & 60.5 \\
\hline
\end{tabular}

Table 4.2: Effect of $\mathrm{pH}$ on adsorption of $\mathrm{Cu} 2+$ for $40 \mathrm{ppm}$ by $\mathrm{RHA}(5 \mathrm{~g})$, for contact time $30 \mathrm{~min}$ at $32{ }^{\circ} \mathrm{C}$

\begin{tabular}{|l|l|l|l|l|}
\hline Sr. No. & $\begin{array}{l}\text { Initial Concentration } \\
\text { of } \mathbf{C u}^{2+}(\mathbf{p p m})\end{array}$ & $\mathbf{p H}$ & $\begin{array}{l}\text { Final } \\
\text { concentration of } \\
\mathbf{C u}^{2+}(\mathbf{p p m})\end{array}$ & \%age adsorption \\
\hline 1 & 40 & 02 & 27.04 & 32.4 \\
\hline 2 & 40 & 04 & 17.50 & 56.2 \\
\hline 3 & 40 & 06 & 4.53 & 88.7 \\
\hline 4 & 40 & 08 & 0.03 & 99.9 \\
\hline 5 & 40 & 10 & 6.29 & 84.3 \\
\hline 6 & 40 & 12 & 12.65 & 68.4 \\
\hline
\end{tabular}

A graph was plotted between the various $\mathrm{pH}$ ranges and \% adsorption. For this purpose, the $\%$ adsorption of different copper standards $(30 \mathrm{ppm}, 40 \mathrm{ppm})$ at various $\mathrm{pH}$ ranges were taken. Various $\mathrm{pH}$ ranges were taken along horizontal axis while the \% adsorption was plotted along the vertical axis. 




Figure 4.1: Effect of $\mathrm{pH}$ on adsorption of copper for $30 \mathrm{ppm}$

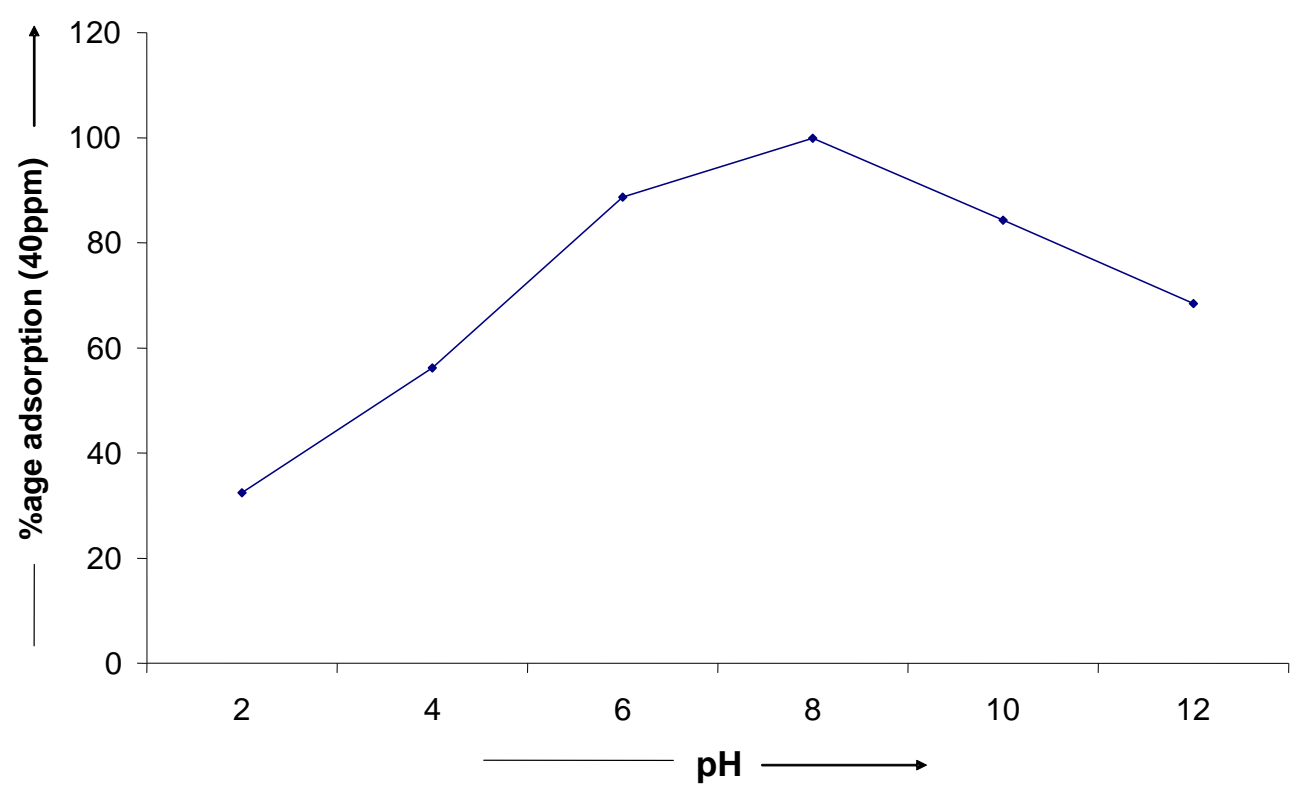

Figure 4.2: Effect of $\mathrm{pH}$ on adsorption of copper for $40 \mathrm{ppm}$

Adsorption of $\mathrm{Cu}^{2+}$ on RHA was analyzed at different $\mathrm{pH}$ ranges (2 to 12). Standard used for this were $30 \mathrm{ppm}$ and $40 \mathrm{ppm}$. pH for each solution of copper(II) standards was studied at 2, 4, 6, 8, 10 , and12. In the solutions of both the concentrations, the adsorption of $\mathrm{Cu}^{2+}$ was maximum at pH $6 \& 8$. With increase in $\mathrm{pH}$, adsorption increases. Adsorption was maximum in slightly acidic solutions (Fig.4.1, 4.2). The minimum adsorption was observed at $\mathrm{pH} 2$. It may be due to the higher concentration and higher mobility of $\mathrm{H}^{+}$ions present. At lower $\mathrm{pH}$ value, the adsorbent surface is surrounded by $\mathrm{H}^{+}$ions, thereby blocking the metal ions to approach the binding sites of adsorbent (Wong et al. 2003). With pH increase, more negatively charged surface becomes available which help in copper removal. Adsorption of metal cations increases with increasing $\mathrm{pH}$ because the metal ionic species become less stable in the solution. 


\section{CONCLUSION}

From the above study, it was concluded that removal of copper from wastewater depend on different factors which may be controlled and adjusted for the removal of copper using rice husk ash. It can also be noted that rice husk ash is good adsorbent as $100 \%$ removal was possible using adsorption technique.

\section{REFERENCES}

[1] Larous S., Meniai A. H. and Lehocine M. B. (2005). Experimental Study of the Removal of Copper from Aqueous Solutions by Adsorption Using Sawdust. Desalination, 185, 483490.

[2] Naeem S., Zahra N. and Zafar U. (2010). Adsorption Studies of Copper on Rice Husk Ash (RHA), Bangladesh Journal of Scientific and Industrial Research, 45, 367-370.

[3] Naeem S., Zafar U., Zahra N. and Rasool G. (2010) Adsorption studies of Copper on Alumina, J. Chem. Soc. Pak, 32, 52-57.

[4] Rameshwar P. and Arun K. (1962). Effect of temperature on the adsorption of Cu2+ , Silver (I), Oxalate (II) and Ferrocyanide (IV) by different samples of precipitated hydrous thorium oxide, Colloid \& Polymer Science, 183, 71-74.

[5] Shukla, A., Zhang, Y., Dubey, P., Margrave, J. L. and Shukla, S. S. (2002). The role of sawdust in the removal of unwanted materials from water. J. Hazard. Mater., B95, 137157.

[6] Tariq S. N., Nazik J. E. and Alya A. D. (2009). Adsorption of Copper and Iron Using Low Cost Material as Adsorbent, E-Journal of Chemistry, 6, 161-168.

[7] Wong K. K., Lee C. K., Low K. S. and Haron M. J. (2003). Removal of Cu and Pb by tartaric acid modified rice husk from aqueous Solutions. Chemosphere, 50, 23-28.

[8] Yates D. M., Joyce K. J. and Heaney P. J. (1998). Complexation of copper with polymeric silica in aqueous solution, Applied Geochemistry, 13, 235-241.

[9] Zahra N., Sheikh S. T., Mahmood A. and Javed K. (2009). Removal of Arsenic from wastewater using Bentonite, Bangladesh J. Sci. Ind. Res., 44, 81-86.

[10] Zahra N. (2009). Adsorption characteristics of Bentonites for Chromium in wastewater, J. Chem. Soc. Pak, 31, 233.

[11] Zahra N., Sheikh S. T. and Javed K. (2008). Batch Adsorption studies of Cadmium in wastewater on Bentonite, J. Chem. Soc. Pak, 30, 797.

[12] Zahra N. (2010). Arsenic Contamination in water and its removal using different low cost adsorbents, A Review, J. Chem. Soc. Pak, 32, 259.

[13] Zahra N. (2014). Studies of various adsorbents for the removal of Cu (II) from drinking water: A review, Asian J. of Adv. Basic. Sci., 02, 70-76. 